\title{
「水文科学が解き明かす不思議な天然水」
}

\section{1. 低温異常を示す鬼押出し末端湧水群}

\section{鈴木 秀和 $* 1$}

\section{I . はじめに}

群馬・長野県境に位置する浅間山は, 現在も 活動を続ける活火山であり, 最近では 2004 年と 2009 年に小規模な噴火活動を起こしている。そ の周辺には数多くの湧水が分布して打り, 山麓地 域の重要な水資源として活用されている。また東 麓には，その優美さから夏季を中心に多くの人が 訪れる, 避暑地軽井沢の主要な観光スポットであ る白糸の滝が湧出する (Fig. 1)。その景観や湧出 機構, 水質特性からみると, この白糸の滝も充分 に不思議（特異）な要素を兼ね備えているが，そ れ以上に特異な性質をもつ湧水が浅間山麓には存 在している。それが今回紹介する，北麓に位置す る「鬼押出し末端湧水群」であり (Fig. 1), 活動 的な火山山麓に位置するにも関わらず，周囲の涌 水に比べ水温が極度に低い「低温異常」を示すこ とが知られている（鈴木・田瀬，2007）。

連載の第 1 回目となる本稿では, 「水温的に特 異な水」として, この鬼押出し末端湧水群におけ る低温異常 (涌水低温現象) を取り上げた。異常 水温と聞いてまず思い浮かべるのは，徳島県吉野 川市 (旧鴨島町) の江川湧水であろう。吉野川の 旧氾濫原にある湧水であり, 確認された当初は冬 に水温が $20^{\circ} \mathrm{C}$ 以上，夏に $10^{\circ} \mathrm{C}$ 以下を示し，気温 と水温の年変化が逆に近い位相を持つことで知ら れていた。これは吉野川から伏流する地下水が温 度を保持しながら，3〜 $5 \mathrm{~m} / \mathrm{day}$ 程度の流速で流
下するために引き起こされる現象であると考えら れている（新井・横畠，1990）。一方，鬼押出し 末端湧水群の湧水温には明瞭な季節変化は認めら れず，一年を通してほぼ等しい温度を保っている ことから, 特有の地下水温形成機構がはたらくこ とによって低温異常を示すことが推定される。今 回は，これまでの研究成果を踏まえてその要因に ついて概説することにしたい。

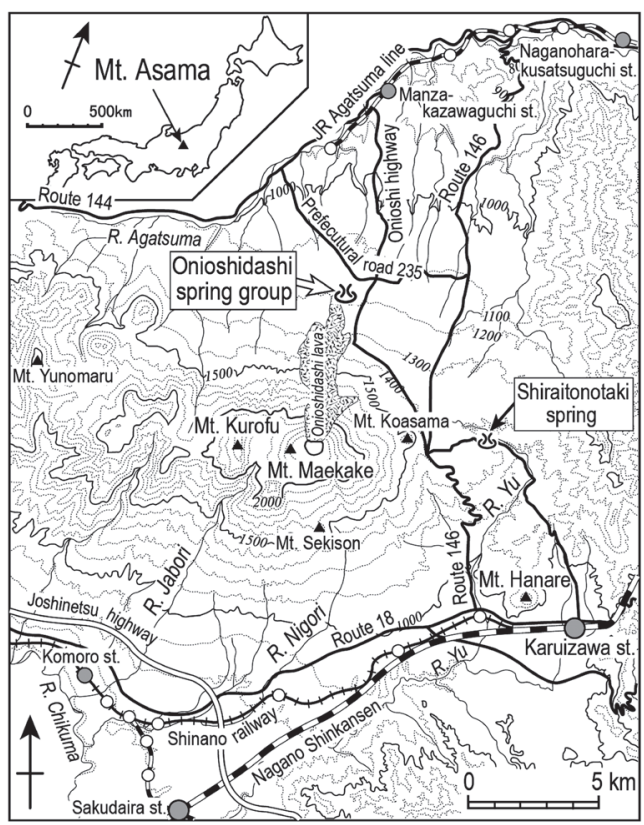

Fig. 1 Location map of springs reported in this article.

* 1 神奈川県温泉地学研究所 


\section{II . 低温異常を示す湧水の位置と概要}

天明（1783 年）の噴火時，浅間山の北斜面に 流出した鬼押出し溶岩流は，その如何とも形容し がたい景観から名勝地として名高く，鬼押出し 園や浅間園といった観光施設が設けられている (Photo 1)。この溶岩流の末端部には集中して数ヶ 所の湧水が確認されている。鬼押出し溶岩流の末 端部は，浅間園（標高 $1400 \mathrm{~m} ）$ 付近に谷頭をも

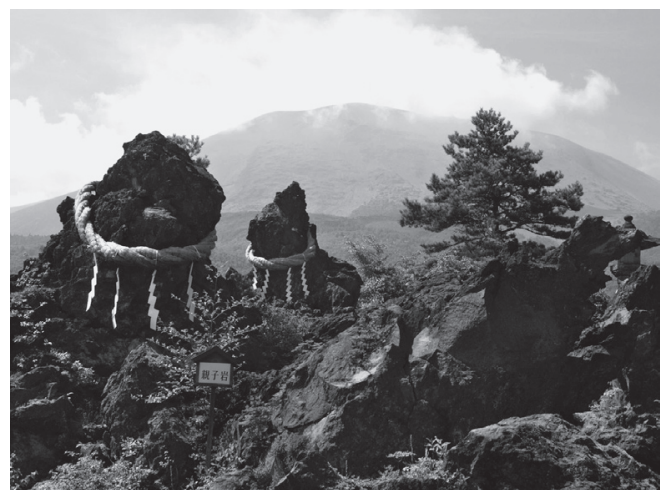

Photo 1 Surface aspect of Onioshidashi lava flow (taken on August 2006).

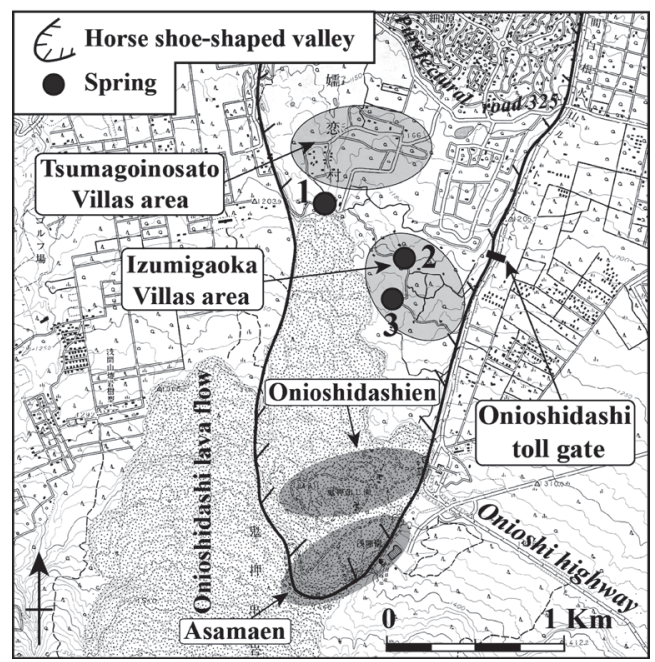

Fig. 2 Location of springs with remarkably low water temperature around the tip of Onioshidashi lava flow. 1:25,000 topographic map "Kitakaruizawa" published by Geographical Survey Institute of Japan is used.
つ深さ数十 $\mathrm{m}$ 以上の馬蹄型谷の一部を埋めてお り，とくに低温異常を示す湧水（No.1～No.3） はこの谷中に位置している（Fig. 2)。

軽井沢方面から鬼押ハイウェーを進み，鬼押 出し園を過ぎた先にある鬼押出し料金所の手前か ら入る泉ヶ丘別荘地内に数ヶ所の涌水 (No.2 と No.3）があり，別荘地の飲用水などに利用されて いる (Photo 2)。各涌水の年平均水温は No.2 が 約 $4{ }^{\circ} \mathrm{C}, \mathrm{No} .3$ が約 $5{ }^{\circ} \mathrm{C}$ である。また, 料金所を過ぎ, 県道 235 号大笹北軽井沢線との十字路を左折した 先に入り口がある「嬬恋の里」別荘地の奥には, 嬬恋村の第一上水道水源として使用されている, 浅間山麓でも最大規模の湧水 $\left(28,000 \mathrm{~m}^{3} /\right.$ day $)$ が 存在している。水道施設のため残念ながら主湧出 口の様子を見ることはできないが，施設脇にある 窪地の溶岩流末端崖基部から，小規模ではあるが 年間を通じて約 $3^{\circ} \mathrm{C}$ と最も低温を示す涌水 (No.1) が湧出している (Photo 3)。

涌水の涌出標高（1170～1220m）よりも若干 高所（標高 $1230 \mathrm{~m}$ ）に位置する，嬬恋村田代（対 象地域の $6 \mathrm{~km}$ 西方）に打ける $7.1^{\circ} \mathrm{C}$ という年平均 気温からみても，湧水温はかなり低温であること が認識される。とくに，気温との差が大きくなる 夏季には，その冷たさゆえにほとんど手を浸けて

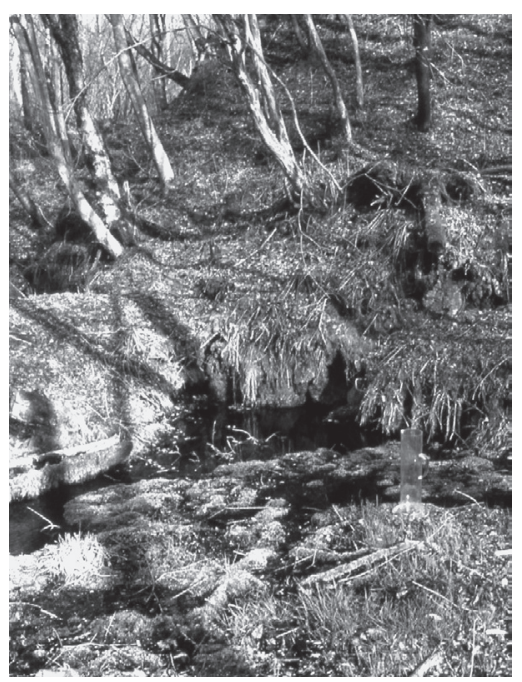

Photo 2 Spring located in the Izumigaoka villas area (No.2; taken on May 1996). 


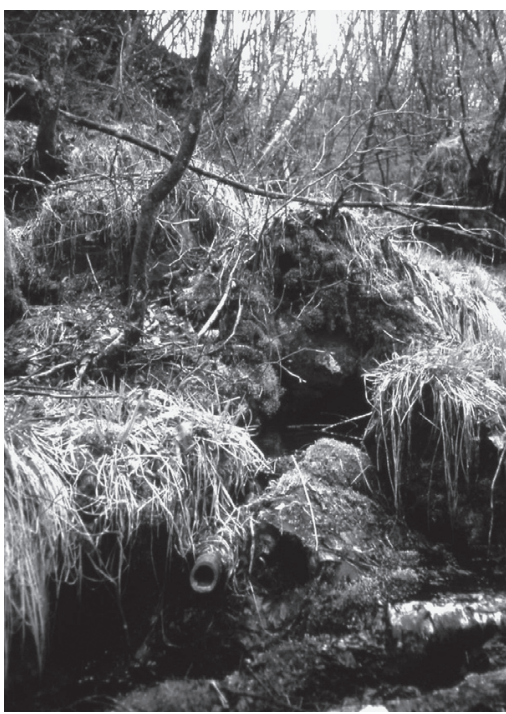

Photo 3 Spring located in the vicinity of water supply facility of Tsumagio village (No.1; taken on May 2003).

おくことができないほどである。またNo.1のす ぐ脇には，後述するように冷気の流出孔があり， 天然のクーラーによって周辺の空気が冷やされ涼 しく感じられる。

また松島（1989）によると，古文書の中に「天 明噴火の際，鬼押出し溶岩の末端部付近より温泉 が湧き出し，それを吾妻川沿いの大笹宿まで引湯 し，湯小屋を建て 2 年後に開業した」との記述が あり，村内の鎌原にある別荘地には，引湯の遺構 が実際にみられるそうである。その後，大笹の湯 は泉温が次第に低下し，文化 3 年（1806）頃廃止 されたそうであるが，その後さらに水温が低下し， 現在に至っているものと推定される。このように 天明噴火直後の鬼押出し溶岩流未端部の湧水は, 現在の状況とは全く異なり，噴出直後の溶岩が持 つ熱の影響により，入浴に適するほど高温になっ ていたことをうかがい知ることができる。

\section{III. 浅間山北麓における湧水温の地域特性}

今回紹介する鬼押出し溶岩流未端部以外にも, 浅間山北麓には数多くの涌水が確認されている

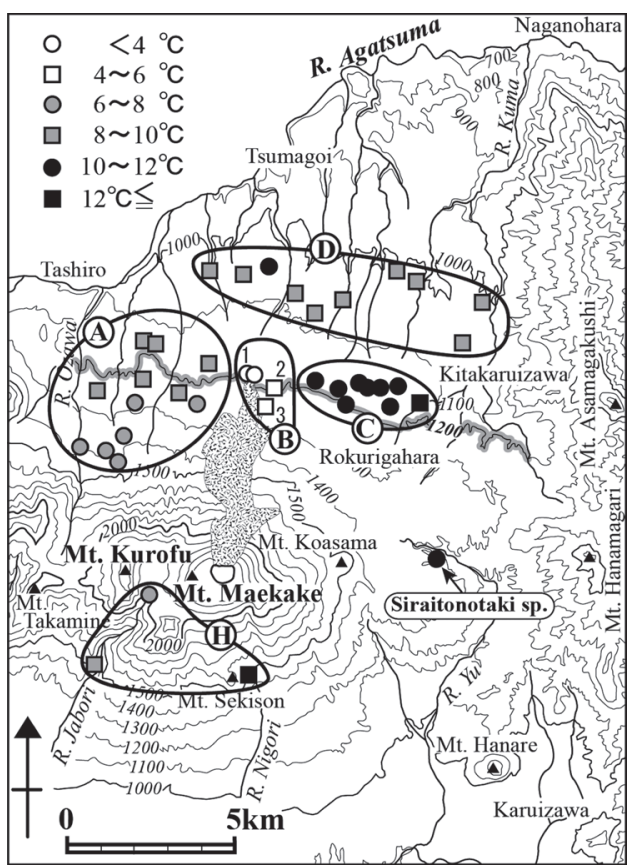

Fig. 3 Regional distribution of spring water temperature on the northern foot of Mt. Asama (modified from Suzuki and Tase, 2007).

The alphabets $(\mathrm{A} \sim \mathrm{D}$ and $\mathrm{H})$ in this figure represent spring groups with similar physicochemical properties.

(鈴木・田瀬，2007)。湧水温の分布を示した Fig. 3 をみてわかるように，標高 $1200 \mathrm{~m}$ の等高線に 沿って分布する涌水の水温が，湧出地域により明 瞭に異なっている。一般的に湧水温と標高の間 には，標高の低下にともない水温が上昇すると いう逆相関の関係がみられる。湧水群 A（黒斑山 麓）と涌水群 D（標高 $1000 \mathrm{~m}$ 付近）の涌水温と 標高の間には，一般的な火山山麓同様，明瞭な逆 相関関係が認められる (Fig. 4)。しかし, 今回紹 介する湧水群 B (鬼押出し末端湧水群) の湧水温 は, 周囲のものに比べ著しく低く, 最も高所（標 高 $1420 \mathrm{~m})$ に位置する涌水よりも $3^{\circ} \mathrm{C}$ 以上も低い。 しかし, そのすぐ東側に位置する涌水群 C（前掛 山麓の六里ヶ原地域）の涌水温は, 逆に $10.0^{\circ} \mathrm{C}$ 以 上の高温を示している。このように同一標高に位 置する涌水でも, それが湧出するまでの過程で受 ける様々な影響により，その性状を大きく異にす 


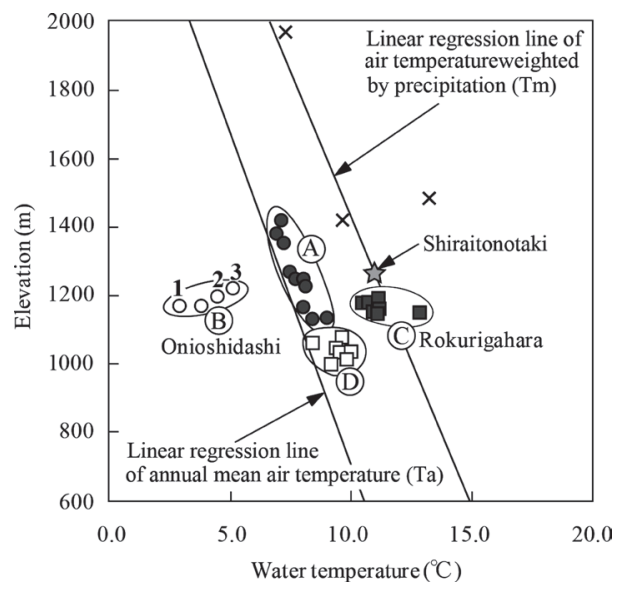

Fig. 4 Relationship between spring water temperature and its elevation.

- : Group A (Northern foot of Mt.Kurofu), $\bigcirc$ : Group B (The tip of Onioshidashi lava flow), 口: Group C (Rokurigahara area), $\square$ : Group D (1000m spring zone), $\times$ : Group H (Upper part of the southern slope)

ることがわかる。また，南斜面の高所に分布する 涌水群 $\mathrm{H}$ は，より火口に近い場所に位置するた め，湧出高度が高いにも関わらず，比較的高い湧 水温を示している。

Fig. 4 には，周辺地域の気温打よびそれを降水 量で重み付けした加重平均值と，標高の関係から 得られた回帰直線も示してある。鈴木 (1994) は, この気温の加重平均值を涵養水温と考え，この線 (平均涵養水温回帰直線：Tm) より右側に位置す る湧水は地熱の影響をうけたものであり，平均気 温の線（平均気温回帰直線：Ta）より左側に位 置する湧水は，大きな流動系を持つもの，つまり 涵養高度がかなり高所にある湧水であると述べて いる。本地域では，大部分の涌水が $\mathrm{Ta}$ と $\mathrm{Tm}$ の 間に位置しているが, 涌水群 B は Ta の左（低温） 側に，そして湧水群 $\mathrm{C}$ と $\mathrm{H}$ は $\mathrm{Tm}$ のより近く, または大きく右（高温）側へ外れてプロットされ ている。

\section{$\mathbb{N}$. 湧水温の形成機構}

まずは，Fig. 4 で高温側にシフトする涌水群 C

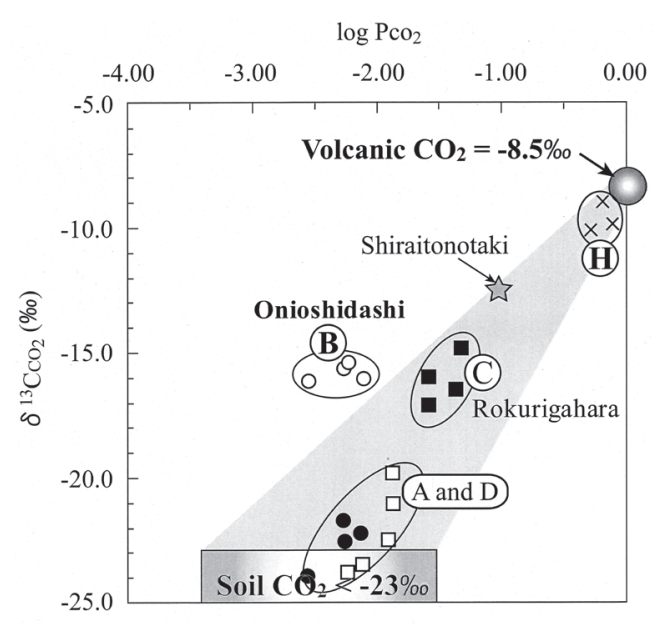

Fig. 5 Relationship between $\log \mathrm{Pco}_{2}$ and carbon isotopic composition of $\mathrm{CO}_{2}$ equilibrated with dissolved inorganic carbon in spring water $\left(\delta^{13} \mathrm{CCO}_{2}\right)$. Shadow part represents the mixing trend between deep derived volcanic $\mathrm{CO}_{2}$ and biogenic soil $\mathrm{CO}_{2}$. The symbol legends in this figure correspond to those in Fig.4.

に打ける湧水温の形成要因について考えてみる。 これらの涌水は，現在も活動中である前掛山の山 麓に位置し，火山活動の影響をうけたと考えられ る $\mathrm{SO}_{4}{ }^{2}$ や $\mathrm{Cl}$ に富む特異な水質特性を示す。鈴木 田瀬（2010）は $\delta{ }^{13} \mathrm{C}$ 值を指標とし，浅間山周辺 に分布する涌水中の溶存炭酸に対する火山性 $\mathrm{CO}_{2}$ ガスの寄与率を求めて打り，涌水群 $\mathrm{A}$ と D では その影響が少ないのに対し，涌水群 Cでは $50 \%$ 程度の寄与率があることを報告している (Fig. 5)。 したがって, 湧水群 C の涌水温は火山活動に伴 い，通常より大きな地熱の影響を受けた結果，他 の湧水群より高温となることが示唆される。また, 白糸の滝湧水も同様の性質を持っていることが示 されている (Figs. 4 and 5)。なお，山頂火口のよ り近くに分布する涌水群 $\mathrm{H}$ では，低温ガスであ るため水温に対し大きな影響を与えることはない が，火山性 $\mathrm{CO}_{2}$ ガスの寄与率が $90 \%$ 以上と非常 に高いことが確認されている (Fig. 5)。

このような高温異常は, 活動的な火山山麓で 良く観察される事例であるが，涌水温が平均気温 
より $2 \sim 3^{\circ} \mathrm{C}$ 低くなる現象は，大きな流動系をな す地下水が涵養地点に打ける水温を維持したまま 流下し湧出しているとされる, 富士山麓で確認さ れているのみである（鈴木，1994）。鬼押出し末 端涌水群に打ける低温異常についても, 同じよう な要因が考えられる。しかし，標高 $1200 \mathrm{~m}$ 付近 に位置し，火山活動による地熱の影響がない湧水 群 A に含まれる涌水温が約 $8^{\circ} \mathrm{C}$ であり, 涵養高度 に関係する $\delta{ }^{18} \mathrm{O}$ 值もほぼ同様の值であることか ら, 本地域に打る低温異常は, 局所的な地温（低 温）の影響をうけた結果であると推定される。

鈴木・田瀬（2007）では，No.1近傍および浅 間園における冷気流出口の存在からみて, 溶岩流 内部は明らかに低温状態にあることが指摘され ている。このような地下空間に打ける低温現象 は, 富士山北麓の溶岩トンネルや日本各地の累石 風穴に打いて確認されている。両者とも冬季に水 点下の冷気が重力流として地下空間内部に流入す ることで，低温状態が作り出される。そして地表 面が高温になる夏季には極めて安定した成層状態 になるため，冬季の低温状態が維持される（Fig. 6; Tanaka et. al., 2000)。塊状溶岩である鬼押出し 溶岩流未端部付近は，大きな岩塊に覆われており 中心部も亀裂に富むことから, 累石風穴形成場と 同じような条件を備えて打り，冷気流出口の存在 から風穴循環系が成り立っていることが示唆され る。このように溶岩流内部の岩塊が年間を通して 低温に保たれていることが，湧水の低温異常を引 き起こす重要な要因であると考えられている。し かし, 低温状態の溶岩流内部に滞留・流動するこ とのみによって, 多量の地下水を $5^{\circ} \mathrm{C}$ 近くも冷却 することが本当に可能であるか，今後は熱収支的 な観点からの考察も必要と思われる。

\section{V. 鬼押出し末端湧水群でみられる水温以外の特 異的な性状}

近年， $\delta^{13} \mathrm{C}$ 值を用いた鈴木・田瀬（2010）の 研究によって, 鬼押出し溶岩流未端部における特 異な湧出形態が明らかにされた。浅間山周辺の涌
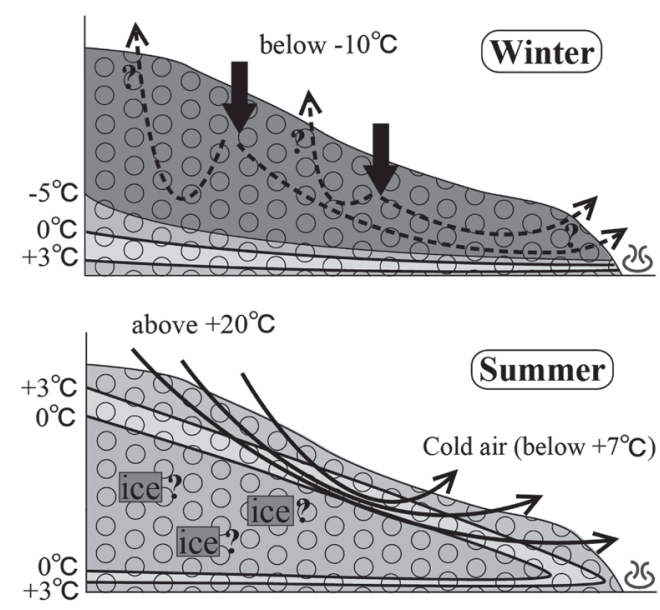

Fig. 6 Schematic representation of wind hole circulation in the tip of Onioshidashi lava flow with interconnected many fractures.

In winter season, relatively high density cold air $\left(<-10^{\circ} \mathrm{C}\right)$ inflows into fractured open space in lava flow, and lava blocks are cooled. In summer season, relatively low density warm air $\left(>+20^{\circ} \mathrm{C}\right)$ never inflow into the deeper part of lava flow because cold condition of that is preserved by temperature stratification. Thus low temperature condition is kept in the interior of lava flow through the year.

水中の溶存炭酸は, 土壌 $\mathrm{CO}_{2}\left(\delta^{13} \mathrm{C}\right.$ 值 $\left.<-23 \%\right)$ と火山性 $\mathrm{CO}_{2}\left(\delta^{13} \mathrm{C}=-8.5 \%\right.$ ）の二成分混合によっ て形成されているが，鬼押出し末端湧水群ではそ の傾向から大きく外れ，比較的高い $\delta^{13} \mathrm{C}$ 值を示す 一方で, $\mathrm{CO}_{2}$ 分圧 $\left(\mathrm{Pco}_{2}\right)$ が低いという特徴が認 められた（Fig. 5)。これは，火山性 $\mathrm{CO}_{2}$ の影響を 受けた地下水が, その流出過程に打いて通気性の 高い溶岩の亀裂系を流動するために溶存 $\mathrm{CO}_{2}$ の脱 ガスが起こった結果と考えられている。

現在の浅間園や鬼押出し園という観光施設が広 がる地域には, 1783 年 (天明) の噴火以前, 柳井 沼と呼ばれる沼沢地が存在していた（山田ほか, 1993)。したがって，この付近は山体斜面で涵養さ れた地下水の流出域であると推定される。現在は $60 \mathrm{~m}$ 以上もの層厚をもつ溶岩流に覆われているた め，地下水は湧水として地表に流出せず，さらに 下方へと通気性の高い溶岩流内部を流動する過程 
で溶存 $\mathrm{CO}_{2}$ が脱ガスし，最終的に溶岩流が途切れ る末端部において湧水として涌出することが予想 される。鬼押出し涌水群の水温や水質に大きな季 節変動がみられないことからも，馬蹄型谷頭付近 に地下水貯留層の存在が推定される。

また近年, $\mathrm{CFCs}$ による地下水の涵養年代の推 定も行われ，No.1の湧水の平均滞留時間が約 30 年であることが推定されている（日本水文科学 会「日本の火山の地下水ワーキンググループ」未 公表データ)。これは雪解けの冷たい水が，透水 性の高い溶岩中を流れ，直接その末端部で涌水と して涌出しているものではないことを意味してお り，地下水貯留層の存在を支持する結果となって いる。

\section{VI. おわりに}

今回は「水温的に特異な水」として，鬼押出し 末端湧水群における低温異常を取り上げ，その要 因であると考えられる地下空間に打ける低温形成 のメカニズムとして, 風穴循環について概説した。 鬼押出し末端涌水群では，通常とは異なる水文環 境を反映した結果，低温異常が引き起こされてい ることが分かってきたが，その全容解明には，さ らなる研究の蓄積が必要とされている。現地への アクセスには軽井沢駅から車で 1 時間程かかる が，夏場の避暑を兼ねて，白糸の滝などと併せて 訪れることを摊めしたい。多くの方にこの涌水 の冷たさを実感していただき，不思議な水の成り 立ちについての興味や見識を深めていただく機会 となれば幸いである。

\section{参考文献}

新井 正 · 横畠道彦 (1990)：徳島県江川付近 の地下水. の温度と流動. 地理学評論, $63 \mathrm{~A}$, 343-355.

鈴木秀和・田瀬則雄（2001）：名水を訪ねて (52) 浅間山麓の名水。日本地下水学会誌，43, 43-49.

鈴木秀和・田瀬則雄（2007）：浅間山北麓におけ る涌水温の形成機構と地域特性. 日本水文科学 会誌，37，9-20.

鈴木秀和・田瀬則雄（2010）：浅間山における 涌水の溶存炭酸の炭素同位体比一火山性 $\mathrm{CO}_{2}$ の寄与率の推定一。 日本地下水学会誌，52, 247-260.

鈴木裕一 (1994）：八ヶ岳の涌水打よび地下水の 水温について，八イドロロジー（日本水文科学 会誌)， 24，83-92.

松島榮治（1989）：「大笹の湯」引湯跡。広報つま ごい, 561, http://interpreter.jp/matsushima_ eiji/001-052/019.html.

山田 孝・石川芳治 · 矢島重美 ·井上公夫 · 山川 克己 (1993)：天明の浅間山噴火に伴う北麓斜 面での土砂移動現象の発生・流下・堆積実態に 関する研究．新砂防，45(6)，3-12

Tanaka, L.H., Nohara, D. and Yokoi, M. (2000): Numerical simulation of wind hole circulation and summertime ice formation at Ice Valley in Korea and Nakayama in Fukushima, Japan. $J$. Meteor. Soc. Japan, 78, 611-630. 